\title{
TECHNOLOGIES OF PSYCHOLOGICAL WELL-BEING FORMATION OF PERSONALITY IN CRISIS SITUATIONS
}

\section{Volodarska N. D.}

\section{INTRODUCTION}

In the context of modern society, the problem of researching the occurrence of the well-being feeling of personality in crisis situations acquires fundamental and crucial significance. Across a variety of life situations, the well-being feeling of personality may arise. It arises along with various socio-cultural, family-generic stereotypes of feelings and experiences. The well-being feeling may arise in the context of values of a particular subculture, which creates conditions for interaction and understanding, unity with other persons. The comfort of mutual relations leaves some pleasant feelings that a person is trying to repeat and feel again. In order to do this, the person recreates similar life circumstances, creates new conditions for appearance of the well-being feeling.

When a person is in a crisis situation, the person's experiences, feelings and emotions change; and a problem arises of adaptation to this situation. Changes in conditions wherein well-being feelings arise, originate some obstacles excluding appearance of this feeling. The person despairs in any changes of own experiences, restoration of feelings of comfort, well-being and happiness. The task emerges of experiences psychocorrection of person who is in crisis life situations.

Considering the ways to optimize the process of persons adaptation who are in crisis situations (in the current context of war in Ukraine), the factor of psychological well-being must be accounted, as far as it leaves its trace in any regularities, ideas, beliefs of personality. The issue of psychological well-being of personality is crucial in a crisis situation. When answering the questions: "What comes next?", "How to achieve own goal?" and "For what?" the person outlines a system of possible perspectives, life purposes, values of unknown future for psychological well-being formation. The person in a state of incertitude, confusion and uncertainty in own abilities of changing something, begins searching new life meanings and changing stereotypes of behavior. 
Urgency of the problem of the psychological well-being formation of personality in the context of military conflict is multilateral and diverse. In conditions of military conflict, problems of temporary displaced persons arise. Their families are afflicted with both material and psychological problems of adaptation in a new social surrounding, new unusual conditions. Lack of familiarity with possibilities of the community assistance in solving problems of personality impedes his/her adaptation in new conditions, mutual relations with a new social surrounding.

Many directions of psychological support exist, in particular, crisis intervention, eco-facilitation method (author Lushin P.V.), NLP, symbol-drama, art-therapeutic methods, projective methods using metaphorical associative maps, transactional analysis, logotherapy and combined methods.

Gestalt-technologies deserve special attention; they can help personality to form a new view of reality, wherein psychological wellbeing is formed. In particular, the dialogical-phenomenological method, as the basis of the Gestalt approach enables the personality to determine differences between own present ideas and reality, opening the possibility of changes.

Awareness that each person has own image of the world, makes it possible to realize that it may be inaccurate, distorted in one or another direction. At the same time, since the world perception may be changed much more easily than the world itself, the awareness of it leads the person to the freedom of view, life perspectives and ideas selection, as well as of their change. When we understand that various life obstacles arise due to our ideas, it leads to assumption of responsibility for overcoming them and creating new life prospects, as well as finding a new life purpose in crisis situation, as conditions of psychological well-being.

Such important dialogical features of feelings and emotions as twovoice texture - polyphony, procedurality - dynamism, gestaltity holistic, differentiation - non-disjunctivity, multifunctionality polysemanticity, ambivalence - relativity and other are insufficiently considered. The well-being feeling requires new rethinking, finding new approaches to understanding the nature of its occurrence.

Therefore, with account of the urgency of problems of the psychological well-being formation of personality, which is in a crisis 
situation, the aim of our research consists in: creation of new methods of well-being feelings formation with consideration of those particular features of emotions; characterization of peculiarities of the technology of psychological well-being formation of personality.

The objectives of our study are as follows:

1. Outline the optimum ways to activate the process of psychological well-being formation of personality in new conditions of social surrounding (formation of life prospects, goals, values, life meanings of personality).

2. Characterize the peculiarities of technologies of group and individual work with personality problems in crisis situations.

\section{Psychological Well-being as a Factor of Social Adaptation of Personality in Crisis Situations}

Analyzing the theoretical approaches to the problem, the basic principles were determined, as well as principles of activation of psychological well-being formation of personality who was in crisis situations. Beliefs and convictions that guide all our actions are short conclusions of our experience. And just like any other findings, they can be limited, distorted and frequently combined, causing a state of frustration. This creates obstacles to the psychological well-being formation of personality. When dealing with personality perplexity and state of frustration, it is important to follow the presupposition method. If a person really accepts the presupposition that people always follow the rules of the best of what they can do, what they are capable of, and then there is no room for offences and accusations of anyone. This is confirmed by Prigogin's theory of bifurcation points in the activity of complex social systems: "There are significant fluctuations near bifurcation points in the systems" ${ }^{1}$.

When such systems face an alternative of several options for further activity, small fluctuation may origin changes, evolution in a completely new direction. This applies to a person in crisis situations. The person can absolutely unpredictably start acting in a new direction (change profession, start new business, get new education, change the efficiency criteria, quality of life, etc.). These views are important within the meaning of impact of social surrounding on the well-being feelings

\footnotetext{
${ }^{1}$ Пригожин, Стенгерс, 1986, с. 56.
} 
formation of personality. Instability in feelings of personality in crisis situations may have an impact on decision making, actions, choice of new values.

Unpredictability of changes in the life values, worldviews of person, who is in crisis, creates difficulties in psychological well-being formation of personality. In the researches of $\mathrm{N}$. Bradburn, the psychological well-being is formed under conditions of maintaining the balance of positive and negative affects ${ }^{2}$.

Satisfaction with life, creating stability in one's own thoughts and life plans, forms the well-being feeling of a person. The first step to this is the certainty of future life plans and prospects, which is confirmed in the papers of D. Leontiev ${ }^{3}$.

Just life orientations and meanings form the basis of psychological well-being. In the papers of Idobayeva O.A. the psychological and pedagogical aspects are distinguished in the research of psychological well-being, which becomes important in the selection of impact factors on this phenomenon formation ${ }^{4}$.

Various methods of psychological support activate the social adaptation of personality to new living environment, new surroundings.

The therapy is aimed at acquisition of communication skills, mutual respect, mutual assistance, aggression in socially acceptable forms, creation of safe environment in order to get support and possibility to share own experiences with those with similar relocation experience.

Groups are created in order to increase the level of psychological culture and psycho-hygiene (trauma, parent-child relations, man-woman relations, conflictology, etc.). Thematic groups of personal development are directed to the search for resource, development of communication skills. The group family therapy is aimed at overcoming aggression, creating trust relationship and comfort in the family.

Particularities of technologies of psychological support to personality and his/her family in the context of social tension within the

${ }^{2}$ Norman M. Bradburn / The Structure of Psychological Well-Being. National opinion research center monographs in social research.

3 Леонтьев Д.А. Тест смысложизненных ориентаций (СЖО). Психодиагностическая серия. М., Смысл, 2006.

${ }^{4}$ Идобаева О.А. К построению модели исследования психологического благополучия личности: психолого-развитийный и психолого-педагогический аспекты. Вестник Томского государственного университета. - 2011. - No351. (2011). 
systematic approach are aimed between family support by the surrounding and ability to rely on oneself.

If a person shifts responsibility for everything that happens to him/her, he/she becomes helpless, powerless, and unable to make any changes. If family members overestimate the importance of their own influence on the surrounding, it creates a feeling of isolation, alienation, shame for interrupting contact with other persons.

In the work on overcoming effects of psychological trauma in the family, attention is paid to personal resources restitution of each its member. First of all, this is a responsibility. Responsibility can only be localized, when intercommunicating in dialogue mode with another family member. Direct manifestations of feelings may become resourceful. Especially such as anger, aggression, which are prohibited at the subconscious level and in reality. Such prohibitions generate in the person passive forms of aggression: gaslighting, manipulation, emotions keeping down, ignoration, sabotage, etc. ${ }^{5}$

In dialogue with other persons, under various circumstances, either clear and explicit or sometimes hidden forms of emotions appear. Sometimes these hidden forms make sense in a particular life situation, as most suitable, adaptive forms.

Activity of personality is considered as manifestation of a certain action towards the surrounding in order to meet one's own needs. The direct manifestation is clear and clearly directed action, wherein expression of emotions is composed of desire or unwillingness laid (I want, I do not want, I love, I am angry, etc.). The passive form of aggression is the action and expression of emotions, which are indirect hidden, but at the same time, aimed at meeting the one's own needs.

The psychotherapy also focuses on personality family resources identification. The family members are aware of certain possibilities for independent decision-making, conditions of financial independence and formation of new relations with the social surrounding. Independence in the relationship with the closest surrounding, helps the person to form own relationship with other persons (change remote interrelations in emotionally warm and close). The therapy strategy consists in the work

5 Володарська Н.Д. Технології психологічної допомоги сім'ям в кризових ситуаціях // Н.Д. Володарська /Збірник матеріалів II міжнародної конференції «Комунікація у сучасному соціумі» (м. Львів, 8 червня 2018р.), - Львів: ЛНУ імені Івана Франка. 2018, - C.101-102. 
on awareness just of the causes of occurrence of certain changes in relationships and uncomfortable situations.

Conditionally, the work with family dysfunctions can be divided into stages:

1 - informing on peculiarities of the family functioning (roles, rules, communications, emotional bond);

2 - analysis of the family genogram (differentiation of "Me", tracking of behavioral patterns that are passed on from generation to generation);

3- intervention in order to determine the nature of family relations (using the Goering board, arrangement with buttons, toys, family photos, family role profiles);

4 - establishing a balance between "take" and "give";

5 - taking responsibility for relations within the family and beyond.

Considering the peculiarities of interaction in the family system, it is possible to determine the recovery factors of well-being feeling of personality and interaction in society.

In crisis situations, the person loses the well-being feeling. Destruction of emotional bonds of personality is one of the most important factors in this process. Renewal of these bonds becomes a condition for formation of the feelings of joy, happiness and well-being. The parental relations are the closest and most important emotional relations for a child as they are in the family system. The idea of family system enables the evaluation of emotional bonds that have developed between its members. Using the notion of personal boundaries in these relationships, it is possible to determine particularities of personality relationship with the social surrounding.

Any system has its boundaries, within frameworks of which the personality has information exchange, changes in values and life strategies. If these frameworks remain unchanged, then certain homeostasis and constancy of forms of information exchange are kept. The aspiration to destroy the boundaries of usual interactions of personality in the society generates the entropy.

In the family life, the balance is kept between destruction (entropy) and homeostasis. The struggle occurs between the desire to keep a wellestablished order of interaction and chaos. The family systems become either more open or closed. 
This struggle destroys or generates the well-being feeling of the family members. Melanie Klein considered the peculiarities of the life strategies formation of personality in situations of loss of emotional bonds with a significant relative ${ }^{6}$.

The way how a child reacts to the loss of emotional bonds in childhood (death of relatives) determines how in the adulthood he/she will react to subsequent losses.

In family relationships, changes occur and exchange of life strategies between members of the system, which causes emotional closeness or remoteness. Emotional bonds are determined by many factors that do not have direct causal connections. They may occur or collapse spontaneously. By examining the complexity of impact of these factors, it is possible to adjust restoration of the well-being feeling of personality.

Emotional bonds as well-being feeling factors of personality affect the well-being formation at various levels (both internally and externally). The family system itself creates or destroys all members of the system. The family system itself creates or destroys these bonds; and all members of the system influence it. Investigating the possibility for changes in the emotional bonds of personality that affect the restoration of well-being feeling, the factors were identified that affect emotional bonds of personality.

Carrying out the technique of unfinished sentences made it possible to identify significant factors of psychological well-being formation of personality. According to the instructions it was necessary to finish the sentence "For me, the psychological well-being is...", "My well-being is interfered with ...». After writing the answers, they were discussed, supplemented with new reflections and conclusions. After the discussion completion, new adjustments were made to the significant factors of personality psychological well-being formation or blocking.

Persons being studied described in detail their understanding of psychological well-being, their feelings, emotions and experiences. Determining what is destroying the psychological well-being, the persons being studied outlined the cases of emotional bonds destruction between parents and children, wives and their husbands, grandchildren

6 Klein M.A. Contribution to the Psychogenesis of Manik-Depressiv States. In Contributions to Psychoanalysis 1921-1945. London. Hogarth Press.p. 948. 
and grandparents, neighbors, teachers and other persons, as well as devaluation of their own feelings, thoughts, etc. They marked the lack of feelings for other persons as the norm of relations wherein security is guaranteed: "What is the reason to take up with other persons and wait for deceit, betrayal". Living emotionally colorless life causes the state of frustration, loss of life meanings: "What is the reason to live like this", "What is interesting in such life", "I do not care, I do not want to change anything, and it is just as well".

The personality imposes certain restrictions on relationships with other persons, setting narrow bounds of individual boundaries. The results obtained were sorted by relevance. Among factors that affect the destruction of psychological well-being of personality the following factors were identified:

- desire for maximum commitment of partner by interaction (that destroys relationships with other persons) that violates personal boundaries of other person (50\% of statements);

- inability to regulate own ambivalence of emotions, desires $(25 \%$ of statements);

- fears of losing emotional intimacy in existing relationships (anxiety and guilt) that originate mechanisms of psychological protection of personality ( $15 \%$ of statements);

- inability to change emotional bonds retention strategies: displacement, rationalization, projection in situations of own internal conflicts (10\% of statements).

Recovery of desirable emotional bonds that become factors of psychological well-being relies on certain obstacles in this process. The obstacles do not allow completion of the case intended and enjoy completion of the started. Under such circumstances, the personality cannot start another deal and plan a new one. This blocks the psychological well-being formation.

The specified features are formed at different ages, starting from early childhood, process of the child separation from mother, which determines the further strategy of building emotionally close relationships. Most often, the persons being studied mention their own childhood, the mother's attitude to them. In cases of the absence of mother in the process of fosterage, further development of offense occurs in the personality, generating feelings of anger, irritation and aggression. The personality in adulthood experiences difficulties in 
relationships with own children. This is confirmed in the research of D. Bowlby related to the formation of a primary feeling of safety ${ }^{7}$ and Melanie Kline in the research of phases of flow of the feeling of loss of a close significant person.

In crisis situations, the personality reverts to conventional strategies for emotional bonds formation, or the searching for new ones occurs. The lack of congruence in the relationship of personality with other persons becomes an obstacle in the psychological well-being formation. The strategy for power manipulation in relationships destroys the feeling of well-being. The absence of hierarchy in the interaction of family members (parents and children, senior and younger) creates chaos and blocks new life strategies. The repetition of old strategies, inability of their renewal, reduces or even blocks the sensibility of personality. The personality loses the ability to realize own feelings, which impedes the psychological well-being. This can even result in blocking the feeling of own body. In such circumstances, the personality loses the acuity of contact with the surrounding.

Such blocking of own sensibility become a barrier for understanding another person. Irritation, emotional and intellectual detachment from what is happening are formed. In such circumstances, the personality does not try to communicate with other persons; he/she only joins the way of existence with them. This conformality, as a way of existence, is determined by the personality as "gray everyday life", "boredom" generating anger, aggression. In such cases, the persons being studied note that they do not even have the desire to clarify, discuss relationships, their own desires with others. Well-being masks of "everything is as it should be" appear on their faces.

The facial expression does not correspond to the internal emotional state of personality. The internal conflict does not come out. The life of personality is in constant confrontation with the world. The introjection is another option of reaction against the manifestation of own feelings and emotions. In this case, the person avoids discussions, lives by the old rules of other persons, "as people say". The personality feels apathy, lack of initiative, submission to authority, giving a delusional feeling of safety. The desire to live "like everyone", by standards, without

${ }^{7}$ Боулби Д. «Привязанность» / Д. Боулби (перевод. с англ.) М., Гардарики. 2003. 
expressing own judgments, complicates making own choices, decisions and psychological well-being formation.

\section{Particularities of Technologies of Psychological Well-being Formation in Therapeutic Groups of Temporarily Displaced Persons}

Research methods. Observations, inquiries, method of unfinished sentences, Gestalt technologies.

Conducting a poll in two therapeutic groups of displaced persons (60 people from Kyiv), most of answers to the question "What assistance is needed first?" were related to allegations (inability of state structures, relatives and family members). Having analyzed the answers, we identified the characteristics of psychological well-being; these ideas were outlined in the concepts: quiet life, stability, joy, support, assistance, determination of plans for the future, do not feel oneselves as excluded people, find a balance of joy in living, faith in humanism, justice, sincerity and purity in human relationships.

Analyzing answers to the questions about difficulties in the psychological well-being formation, it was distinguished: cruelty, sudden loss of material wealth, necessary connections, housing, instability and absurdity of changes in life plans, changes in habitual life, fears, acute anxiety and excitement.

The feeling of weightlessness was identified in many statements: "the feeling that I live between heaven and earth, in a strange city, apartment. I'm not living my life". The most painful questions were: "How to live further on?! With what means to live? How is it possible to survive and forget the horror that haunts at night and stays in the eyes? Who is responsible for horrific death of innocent people?"

As the basis for selection of methods of psychological support, we highlighted the new vision formation of opportunities in achieving wellbeing of personality, not just constraints. With account of identified characteristics of psychological well-being for this group of migrants, the tools of Gestalt technology were selected. The practice of Gestalt approach assumes the primacy of emotional phenomena over all others. The holistic nature of the foundations of this approach conveys the specificity of mental processes that characterize the personality function and behavior, which are relevant to the ego function. These processes 
assume great importance in activating the process of the psychological well-being formation of personality.

The exercise to reformulate messages in the dialogue gives the effect of new vision of restrictions in certain life situations. The fact that appears impossible is seen differently. The time factor is important in solution of these opportunities. Consideration of time limits leads to the thought of prospect of a person's life projects. The majority of displaced persons $(85 \%)$ are focused on the provision of financial assistance for psychological well-being formation; with time (two, three years after movement from places of military events) the problems of changing professions, place of work, residence and further education become actual.

When applying this method, the majority of persons being studied had a shift in interest in behavioral strategies (from management, organization of actions to critique and submission; from the filling strategy and space development to management and organization of actions). In the course of discussion in the group, it emerged that such changes occur in crisis situations (loss of health, material well-being, housing, work, opportunities for free life choice).

A person, who has lost ease in relationship creation and sensitivity to the external environment, after reformulation by other people of his/her problems, begins to contact and create relationships with other persons and himself/herself. The person starts constructing the lost parts (feelings, needs, attitudes) of an integral personality. The viewing the personality problems by other persons changes his/her attitude to this problem. These changes are influenced by humor, reduction of some limitations, and increase in other problem-solving capabilities.

The amazement of person at such transformations in the vision of his/her problem, changes accents in the difficulties of achieving other life goals, formation of these goals. According to the group participant: "Recently I pay attention to reduction of the level of expectations from events; then the real events become more interesting, there is no irritation and insults caused by inflated expectations. I try to look at events from another point of view, positive. This allows me to see the difficulties alternately, with less anxiety, more quite, moderate, with a "breath of fresh air"".

In the group therapy, participants compare their thoughts about certain events with the world outlook of other persons. Conducting the 
exercise to "decatastrophizing" the problem situation, the changes were noted in the attitude of participants to these problems, amazement at the difference in vision of the problem solution. The uncertainty of some persons was compensated by confidence, resilience of other persons: "We are migrants, persistent and tenacious people, able to defend own rights and take responsibility for own actions". It became a support for unsure, confused people, helping to reduce their anxiety level, adopt different positions in crisis situations: "We are all different, but the mentality is similar because we are Ukrainian".

Exercises to uphold own boundaries help to negotiate with other persons possessing own position. Participants are asked to outline their own boundaries with a rope (one rope is given to two persons, which is required for each person to outline own territory on the floor). When negotiating with other persons, participants learn to be calm and moderate in their choices.

Having completed the exercise, the participants share their associations: "It is difficult to negotiate if it is important in your life, but it is necessary do not stay for a while, do not get lodged for a long time. It is necessary to keep going without strain, rush and bustle". When doing the exercise, it is important do not accelerate the negotiations in pairs. The participants gradually calmed down, relaxed, began to talk about themselves more quietly (about their desires, plans). One participant shared her experiences: "It's like life. It is important do not miss and notice the meeting with oneself, own wishes, do not pass by. In the fuss it is difficult to do this. People may not hear, understand and see you".

Any phenomena faced by a person have for him/her emotionalsensual content, meaning and value. Just such approach makes it possible to consider personal feelings in the context of values. Emotional and affective manifestations are interrelated with other mental mechanisms as components and determinants of feelings. These features reflect the particular context of this being. This context, in such feelings as tenderness, warmth, cordiality, sincerity, and sense of confidence, create foundations for the feeling of well-being. Not all these feelings are easy to be empirically studied, but they create conditions for the feeling of well-being.

In the life of person, these feelings arise in the plane of unconscious, sometimes it is difficult to differentiate them among other 
feelings. The person confirms the appearance of the well-being feeling, but it is difficult to explain what generates it. In certain circumstances, this feeling can either arise or disappear. Sometimes it is difficult for a person to actualize the reasons for these changes. It can be a change in the value context of life circumstances. The same conditions can carry different values. By evaluating words spoken with different implications and emotional coloring, the personality changes his/her feelings. The language and culture determine the values of what a person has heard and said. The substantive component of these feelings is conditioned by their intersubjectiveness.

This context of life circumstances is taken into account in psychocorrective methodologies. A person who is in crisis situations has special experiences (loss of life purposes, life prospects, opportunities, limitations and others). Diverse in value feelings are included in this complex of experiences. Among them there are feelings from the past of personality that he/she already knows and has the experience to cope with their experiences. In situations where new, unfamiliar experiences arise, a person can manifest frustrations, fears, panic attacks, insomnia, and other states. Just in such situations the person needs the psychological support.

When developing the methodology, we accounted the focus of psychological support on the awareness by personality of one's own abilities in solving problem situations, acquiring the skills of compromising solutions, changing emotional response, restraining impulsive decisions, establishing relationships in the family. The psychological support is directed to changes in the emotional-volitional and motivational-semantic spheres that affect the well-being feeling of personality. With account of peculiarities of the mutual influence of the well-being feeling and life-purpose values, we developed the methodology "My Well-being Feelings". It allows researching of objective, subjective and intersubjective feelings and experiences of personality.

The intersubjective and associative methodology "My Well-being Feelings" provides great opportunities for studying feelings and emotions, semantic orientations and values of person. The methodology contributes to the restoration or enhancement of personality sensitivity, change of values in the process of restructuring psychological protections, life purposes and goals. These changes occur at three levels: 
cognitive, emotional and behavioral. The person begins searching the life purposes, more realistic expectations appear, the worldview and selfimage expand, new life prospects, goals, life strategies appear, as well as feelings of pleasure, well-being. The methodology creates conditions for analysis of own feelings, causes of internal conflicts, manifestation of aggression or tolerance in conflict situations with other people, finding a compromise in interrelations with them.

According to the methodology instruction, the researcher should consistently pull down the fingertips into small containers with various filling: sand (dry, wet), cereals, small stones, agrimony, dried and fresh flowers, cotton, flour, starch, etc. After change of each container, the fingers shall be wiped with wet napkin. Immersing fingers in the container, it is necessary to note own feelings, associations, memories, fantasies, desires that arise, listen to each change in feelings.

After completion of this procedure, it is necessary to draw and tell about own feelings and associations, paying special attention to pleasant, positive ones that create the well-being feelings. Further on, discuss own experiences in the group or in the course of individual therapy. Prior to the discussion of own impressions, feelings and experiences, it is necessary to draw the most positive ones. It can be done in one drawing or in several drawings (positive impressions are placed in each drawing). Finding of positive image forms a personal resource for change of attitudes to a crisis situation.

Actualization of own feelings, experiences, desires, fantasies creates new meanings, values, re-evaluation of positive and negative parts in own life experience. The differentiation occurs of feelings of anger, dissatisfaction, indifference, joy, pleasure and others. Just changes in these experiences, in evaluation of difficulties in overcoming complicated life situations become a condition for personal relations adjustment.

When discussing the impressions related to these tasks, certain triggers are highlighted of emergence of well-being feeling, changes in the person's attitude to crisis situations, vision of positive sides, new perspectives in certain life situations. As a result, the space is created for significant social interactions, relationships, new decisions in complicated situations of unpredictability and uncertainty. It helps to move from destructive to positive model of personal behavior, see own life in other perspective, master new social norms. It changes the life 
meanings and feelings of well-being, as well as attitude to a crisis situation.

Combination of methods of projective diagnostics, task-based monitoring and Gestalt therapy in tasks discussion, acts as both diagnostic tools and corrective ones. Diagnosis of personal experiences enables the person to actualize them and give some value and meaning. Correction occurs with the change of these values in the hierarchy of personal values, life strategies and behavioral stereotypes.

The methodology of associative-sensual focus-reconstruction of experiences of the personal life path history reveals peculiarities of perception of emotional relationships with other persons (colleagues, neighbors, family members). Just the analysis of emotional bonds, affection, dependence, psychological protection, emotional proximity in interaction with other persons activates personal resource, approval of positive changes in attitude to crisis situations. In cases when the person experiences the lack of explanations, he/she feels confused, anxious, fearful of losing control over expression of own experiences.

By evaluating words spoken by the person being studied, their certain context and emotional coloring, the personality actualizes own feelings. Just the conceptual component of these feelings is determined by their intersubjectiveness. The language and culture determine the values of what a person has heard and said. The methodology "My Wellbeing Feelings" offers wide opportunities to study objective, subjective and interpersonal feelings and values of person. The methodology is based on the dialogical-phenomenological approach that is directed at understanding by the person of own feelings, experiences, desires, their acceptance and ability to speak about them with other persons.

The well-being feeling can arise in the context of values of a particular subculture, which creates conditions for interaction and mutual understanding, unity with other persons.

We identified the most actual problems, forms and methods of psychological support in regulation of interaction between the person and community in conditions of temporary relocation.

1. Educational program on TDP (Temporary Displaced Persons) status. Provision of knowledge of legal rights, benefits, support opportunities to TDP. 
2. Information memo on support provision to TDP (telephone numbers, websites of centers for TDP support, legal support, psychological counseling, psychotherapy).

3. Informing on options of the recreation organization (clubs for family rest, days off, family quest, concerts, yoga, dancing in clubs, park outdoors, etc.).

4. Organization of support groups, mutual support of people with similar life experience. Sharing experiences among displaced persons in online and offline groups.

5. Organization of wellness, educational programs for children, adolescents (personal growth groups, leadership schools, etc.). Organization of fairs, "Handmade" workshops, excursions to other cities and historical monuments of Ukraine.

6. Thematic psychotherapeutic groups (health issues, settlement and prevention of family conflicts, parenting, problems of age-related crises, etc.).

7. Support to displaced persons of 55+ age category (support groups: "Zhytelyub" Center, "Mode" Group, "Active Citizenship" website, Third Generation University).

8. Involvement of psychologists in the work with TPD (Temporary Displaced Persons).

9. Problem of bullying. Reduction of the negative background in relations with local residents and those who "arrived", "come", "limped up", etc.

10. Support for psychologists, organizers of work with people in crisis situations, prevention of professional burnout. Organization of supervision for psychologists, psychotherapists, social workers.

\section{CONCLUSIONS}

Restoration of emotional bonds of personality in communication, interaction with the surrounding is the most important factor in the process of the psychological well-being formation of personality.

Significant factors in blocking the psychological well-being formation of personality are as follows: loss of personality sensitivity, loss of ability to percept own feelings, own body, devaluation of manifestations of own feelings and thoughts. 
Blocking of own desire manifestations leads to the loss of personal security, destruction of own boundaries, which makes it impossible the well-being feeling.

In the application of technologies for psychological well-being formation of personality, the primacy of the therapeutic process, in particular, contact with respect to the effect of therapy, is important. Successes in enhancing the psychological well-being formation become a secondary product of the therapeutic process; they cannot be achieved in any direct way.

Focusing in the therapy on the result with desire to achieve a particular goal most often complicates, inhibits or completely impedes the process of psychological well-being formation. The personal feeling of well-being is formed, and then the idea of well-being appears, composing as a result the integrated picture.

It is important in the selection of forms and methods of regulation the interaction of personality and community to achieve the predictability and identity of personality in relations with the surroundings, formation of self-organizing and self-determining system of relationships. This will help to move from uncertainty and chaos to finding compromises, understanding and harmony in relationships in new surroundings.

\section{SUMMARY}

The research objective is to clarify the peculiarities of perception by personality of obstacles in the well-being feelings formation, significance of life prospects of personality who is in a crisis situation. On the basis of the intersubjective concept of person's interaction with his/her social surrounding, the possibilities of changes in the manifestations of this feeling are identified.

These experiences and feelings of well-being are analyzed in the context of the hierarchy of values of personality and determination of patterns of their occurrence through self-actualization, openness, sincerity and so on. As a result, it is shown that the paradigmatic concept of psychological phenomena of the affective sphere of person reveals patterns of the well-being feeling formation depending on the context of life values of personality.

In each of these life contexts the well-being feeling of personality may arise. It arises along with various socio-cultural, family-generic 
stereotypes of feelings and experiences manifestation. Methods of Gestalt approach are determined in the therapy of overcoming consequences of personality psychotraumatization.

The features are identified of the process activation of the wellbeing feeling of personality restoration by means of Gestalt therapy. Examples are given of psychotherapeutic means in dealing with the problems of psychotraumatization of family members of temporary displaced persons.

The ways are identified of optimization of the process of personality adaptation, restoration of the personal resource and overcoming consequences of psychotraumatization. The narrative method activates changes in awareness of the context of life problems.

The methodology is aimed at changing the attitude of personality to own strategy of behavior and emotional response in crisis situations. The analysis of personality statements during the methodology performance is aimed at determination of features of the well-being feeling formation. These are memories of past situations of well-being in the life of personality, his/her impressions, and fantasies. The proposed method of own personal experiences and life stories description allows to consider them from different perspectives.

The systematicity principle helps to consider the problem of psycho-correction of the well-being feeling of personality, by analyzing his/her feelings, actions and contexts of problematic life situations.

\section{REFERENCES}

1. Пригожин, Стенгерс, 1986, с. 56.

2. Norman M. Bradburn / The Structure of Psychological WellBeing. National opinion research center monocraphs in social research.

3. Леонтьев Д. А. Тест смысложизненных ориентаций (СЖО). Психодиагностическая серия. М., Смысл, 2006.

4. Идобаева О. А. К построению модели исследования психологического благополучия личности: психолого-развитийный и психолого-педагогический аспекты. Вестник Томского государственного университета. - 2011. - № 351. (2011).

5. Володарська Н. Д. Технології психологічної допомоги сім'ям в кризових ситуаціях // Н. Д. Володарська / Збірник матеріалів II міжнародної конференції «Комунікація у сучасному 
соціумі» (м. Львів, 8 червня 2018 р.),- Львів: ЛНУ імені Івана Франка. 2018. - С. 101-102.

6. Klein M. A. Contribution to the Psychogenesis of ManikDepressiv States. In Contributions to Psychoanalysis 1921-1945. London. Hogarth Press. P. 948.

7. Боулби Д. «Привязанность»/ Д. Боулби (перевод. с англ.) М., Гардарики. 2003.

\section{Information about the author:} Volodarska N. D.

PhD in Psychology, Senior Researcher, Leading Researcher of the Laboratory of Personality Psychology of G.S. Kostuk Institute of Psychology National Academy of Educational Sciences of Ukraine

2, Pankivska str., Kyiv, 01033, Ukraine 